\title{
PENGARUH PELATIHAN TERHADAP KINERJA PERANGKAT DESA PADA DESA PINANG BANJAR KECAMATAN SUNGAI LILIN
}

\author{
Hendry Wijaya, Dessy Berlianti
}

\begin{abstract}
ABSTRAKSI
Penelitian ini bertujuan untuk menjelaskan apakah Pelatihan mempunyai pengaruh terhadap Kinerja Pegawaipada Perangkat desa Pinang Banjar Kecamatan Sungai Lilin Kabupaten Musi Banyuasin Sekayu.Sampel menggunakan rumus Slovin.Metode pengumpulan data yang digunakan adalah dengan memberikan kuesioner kepada Perangkat desa Pinang Banjar Kecamatan Sungai Lilin Kabupaten Musi Banyuasin Sekayu.Data dianalisis dengan menggunakan Metode Kuantitatif yaitu menggunakan uji validitas, uji reliabilitas, analsis regresi sederhana, analsis korelasi, analisis determinasi, dan uji t dengan bantuan software SPSS 20.0 for windows. Hasil penelitian menunjukkan bahwa Pelatihan mempunyai pengaruh terhadap Kinerja Pegawai padaPerangkat desa Pinang Banjar Kecamatan Sungai Lilin Kabupaten Musi Banyuasin Sekayu. Koefesien Manajemen Hubungan Pelanggan bertanda positif menandakan hubungan yang searah, dengan kata lain pelatihan kerja akan berpengaruh secara signifikan terhadap Kinerja Pegawai padaPerangkat desa Pinang Banjar Kecamatan Sungai Lilin Kabupaten Musi Banyuasin Sekayu. Hubungan antara Pelatihan terhadap Kinerja Pegawai menunjukkan hubungan yang kuat $(\mathrm{R}=0,640)$. Koefisien determinasi atau angka $R$ square adalah sebesar 0,410 yang artinya adalah $41 \%$ variabel Kinerja Pegawai dipengaruhi oleh Pelatihan.
\end{abstract}

Kata Kunci: Pelatihan, Kinerja Pegawai, Manajemen Sumber Daya Manusia.

\section{Pendahuluan}

\section{Latar Belakang}

Suatu organisasi didirikan karena mempunyai tujuan yang ingin dicapai.Dalam mencapai tujuannya setiap organisasi dipengaruhi oleh perilaku dan sikap orangorang yang terdapat dalam organisasi tersebut.Keberhasilan untuk mencapai tujuan tersebut tergantung kepada keandalan dan kemampuan pegawai dalam mengoperasikan unit-unit kerja yang terdapat di organisasi tersebut, karena tujuan organisasi dapat tercapai hanya dimungkinkan karena upaya para pelaku yang terdapat dalam setiap organisasi.

Menurut Simamora (2006), pelatihan adalah proses pembelajaran yang melibatkan perolehan keahlian, konsep, peraturan, atau sikap untuk meningkatkan kinerja tenaga kerja pegawai. Sumber Daya Manusia merupakan unsur yang strategis dalam mentukan sehat tidaknya suatu organisasi. Pengembangan SDM yang terencana serta berkelanjutan merupakan kebutuhan mutlak terutama untuk masa depan organisasi.

Manajemen sumber daya manusia merupakan sarana untuk meningkatkan kualitas manusia, dengan memperbaiki sumber daya manusia, meningkatkan pula kinerja dan daya hasil organisasi, sehingga dapat mewujudkan pegawai yang memiliki disiplin dan kinerja yang tinggi sehingga diperlukan pula peran yang besar dari pimpinan organisasi, dalam meningkatkan kinerja pegawai diperlukan analisis terhadap faktor-faktor yang mempengaruhinya dengan memperhatikan kebutuhan dari para pegawai, diantaranya adalah terbentuknya pelatihan yang baik dan terkoordinasi.

Menurut pendapat Moeheriono (2012), menyatakan bahwa kinerja merupakan gambaran mengenai tingkat pencapaian pelaksanaan suatu program kegiatan atau kebijakan dalam mewujudkan sasaran, tujuan, visi dan misi organisasi yang dituangkan melalui perencanaan strategis suatu organisasi. Selain itu kinerja seseorang dipengaruhi oleh 
tingkat pendidikan, inisiatif, pengalaman kerja, dan motivasi pegawai. Manusia harus menjadi perhatian dan disiapkan untuk melaksanakan berbagai macam tugas dan tanggung jawab yang akan diembannya, sehingga setiap lembaga atau organisasi dituntut untuk memiliki sumber daya manusia yang mempunyai kinerja yang tinggi agar dapat membangun suatu lembaga atau organisasi kearah yang lebih baik. Menurut Tika (2012) kinerja sebagai hasil-hasil fungsi pekerjaan/kegiatan seseorang atau kelompok dalam suatu organisasi yang dipengaruhi oleh berbagai faktor untuk mencapai tujuan organisasi dalam periode waktu tertentu.

Kinerja pegawai merupakan salah satu tolak ukur dari keberhasilan suatu organisasi atau lembaga, dan demi tercapainya suatu tujuan organisasi atau lembaga yang optimal, dibutuhkan kemampuan dari pucuk pimpinan untuk memperhatikan kecakapan hubungan antara staf atau pegawai yang mengarah pada pembinaan dan pemberian motivasi kepada pegawai, sehingga pegawai dapat memahami tugas dan tanggung jawab masing-masing serta mematuhi aturan-aturan yang telah ditetapkan dalam organisasi atau lembaga tersebut.

Aparatur pemerintah desa dalam hal ini kepala desa beserta perangkatnya, serta lembaga desa seperti BPD, LPM, dan juga kepala dusun merupakan aparat pemerintahan di tingkat yang paling dasar mempunyai tugas untuk melayani masyarakat.Untuk itu Kepala Desa Pinang Bajar Kecamatan Sungai Lilin, mengadakan acara pelatihan peningkatan kapasitas perangkat desa dan lembaga desa serta pelatihan kepribadian yang sering dilaksanakan 3 kali dalam setahun.Kegiatan ini merupakan program tahunan dari desa dengan tujuan untuk meningkatkan kapasitas aparatur desa, lembaga desa untuk menuju perberdayaan masyarakat dalam rangka partisipasi untuk membangun desa agar lebih maju lagi. Kegiatan ini adalah merupakan program tahunan yang ada di desa, dan terus akan laksanakan dengan menggunakan dana desa, karena keberhasilan kinerja dari aparat desa serta lembaga desa akan berdampak pada keberhasilan program pemerintahan desa kedepannya.
Berdasarkan observasi pada pra penelitian yang telah dilaksanakan pada kantor Desa Pinang Banjar dengan melihat aktivitas perangkat desa sebagai tolak ukur dalam penelitian ini menunjukkan bahwa, prestasi kerja perangkat desa belum maksimal, hal ini dapat dilihat dengan ditemukannya beberapa perangkat desa yang belum memahami tugas dan tanggung jawab yang diberikan. Hal tersebut akan berdampak terhadap tanggungjawab pegawai untuk menyelesaikan pekerjaan. Selain itu ketaatan perangkat desa terhadap peraturan perundang-undangan dan peraturan kedinasan belum sesuai yang diharapkan. Hal tersebut dapat dilihat dengan masih ditemukan beberapa perangkat desa tidak ditemukan di tempat pada saat masyarakat akan melakukan dan melengkapi peryasaratan pengurusan administrasi kependudukan, diketahui dari hasil wawancara Penulis dengan beberapa masyarakat masih ada beberapa seperti RT/RW yang tidak adaditempat atau pergi kekebun sehingga membuat masyarakat menunggu untuk meminta blangko persyaratan dalam pengurusan administrasi kependudukan. Selain itu juga diketahui masih ada beberapa pegawai kantor desa yang kurang tepat waktu dalam menyelesaikan pekerjaan kantor dikarenakan adanya pegawai yang meninggalkan kantor pada jam kerja hanya untuk keperluan pribadi.

Berdasarkan observasi yang penulis lakukan pada kantor desa Pinang Banjar Kecamatan Sungai Lilin, kantor desa merupakan ujung tombak pelayanan kepada seluruh lapisan masyarakat, tentunya kantor desa harus memiliki mutu pelayanan yang baik. Namun pada kenyataannya masih belum sepenuhnya dapat memberikan pelayanan yang berkualitas, seperti rendahnya informasi mengenai waktu pelayanan, lama penyelesaian pelayanan, persyaratan teknis dan administrasi yang terkesan berbelit-belit, dan masih ada pegawai tidak menjalankan tugas tepat waktu, kebiasaan keterlambatan pegawai datang ke kantor dan keluar kantor pada saat jam kerja, sehingga banyak masyarakat yang menunggu waktu dimulainya pelayanan, selain itu perilaku pegawai kantor desa yang kurang baik 
juga ditunjukan dari kurang disiplinnya pegawai dalam menjalankan tugasnya.

Kantor Desa Pinang Banjar dinilai perlu mengadakan pelatihan yang wajib diikuti seluruh pegawai mulai kantor desa sampai pada tingkat perangkat desa seperti kepada dusun, Rukun Warga dan Rukun Tentangga, adapun pelatihan yang sering dilakukan kantor kepada desa untuk membina perangkat desa dalam menjalankan tugas pokok dan fungsinya adalah pelatihan peningkatan aparatur desa. Ditinjau dari aspek keterampilan yang dimiliki oleh perangkat desa, masih ditemukan beberapa perangkat desa yang membebankan pekerjaannya kepada perangkat desa yang lain, hal ini disebabkan karena kurangnya keterampilan yang dimiliki oleh pegawai kantor desa dan perangkat desa tersebut, serta adanya kebiasaan pegawai kantor desa dan perangkat desa yang sering menunda pekerjaan yang pada akhirnya pekerjaan menjadi bertambah. Fenomena itu tampaknya sudah menjadi kebiasaan pegawai, sehingga sangat berdampak terhadap kinerja pegawai.Apabila hal tersebut dibiarkan oleh pejabat yang bertanggung jawab dalam menciptakan pegawai negara yang berdaya guna dan berhasil guna, maka visi dan misi yang diemban oleh Kantor Desa Pinang Banjar tidak dapat terwujud sesuai dengan yang diharapkan.

Kantor desa sudah mencoba mengatasi masalah tersebut dengan mengadakan berbagai pelatihan guna meningkatkan kinerja pegawai desa, sehingga dapat memberikan pelayanan kepada masyarakat dengan optimal.Namun hal tersebut tidak berjalan dengan baik karena banyak dari pegawai desa tidak mengikuti pelatihan tersebut dengan berbagai alasan. Berdasarkan keadaan yang telah dijelaskan diatas peneliti tertarik untuk melakukan penelitian dengan judul: "Pengaruh Pelatihan Terhadap Kinerja Perangkat Desa Pada Desa Pinang Banjar Kecamatan Sungai Lilin”.

\section{Perumusan Masalah}

Berdasarkan fenomena yang telah dikemukakan maka rumusan masalah dalam penelitian ini adalah bagaimana pengaruh pelatihan terhadap kinerja perangkat desa pada Desa Pinang Banjar Kecamatan Sungai Lilin?

\section{Tujuan Penelitian}

Tujuan dari penelitian ini adalah untuk mengetahui bagaimana pengaruh pelatihan terhadap kinerja perangkat desa pada Desa Pinang Banjar Kecamatan Sungai Lilin.

\section{Tinjauan Pustaka Pengertian Pelatihan}

Untuk meningkatkan kualitas Pegawai Kantor Desa sebagai abdi masyarakat sangat perlu dilakukan pelatihan. Pelatihan yang selanjutnya disebut diklat adalah proses belajar mengajar guna meningkatkan kompetensi pegawai. Mangkunegara (2007), pelatihan adalah suatu proses pendidikan jangka pendek yang mempergunakan prosedur sistematis dan teroganisir dimana pegawai non-managerial mempelajari pengetahuan dan keterampilan teknis dalam tujuan terbatas. Menurut Pramudyo (2007) Pelatihan adalah Proses pembelajaran yang dirancang untuk mengubah kinerjaorang dalam melakukan pekerjaan. Proses kegiatan pelatihan terkadang diberikan setelah karyawan tersebutditempatkan dan ditugaskan sesuai dengan bidangnya masingmasing.

Berdasarkan pendapat diatas maka dapat disimpulkan bahwa pelatihan adalah suatu proses dimana orang-orang peningkatan kemampuan tertentu untuk membantu suatu pencapaian tujuan organisasi.

\section{Tujuan Pelatihan}

Menurut Sutrisno (2019), pelatihan ditujukan untuk melengkapi keterampilan dalam melakukan pekerjaan, serta mampu menggunakan peralatan kerja dengan tepat. Sedangkan Menurut Pasal 9 Undang-Undang No 13 tentang Ketenagakerjaan Tahun 2003, tujuan pelatihan kerja diselenggarakan dan diarahkan untuk membekali, meningkatkan, dan mengembangkan kompetensi kerja guna meningkatkan kemampuan, produktivitas, dan kesejahteraan.Selanjutnya dalam Peraturan Pemerintah Nomor 101 Tahun 2000 tentang Pendidikan dan Pelatihan Jabatan disebutkan bahwa Diklat bertujuan: 
1. Meningkatkan pengetahuan, keahlian, keterampilan, dan sikap untuk melaksanakan tugas jabatan secara professional dengan dilandasi kepribadian dan etika pegawai sesuai dengan kebutuhan organisasi.

2. Menciptakan pegawai yang mampu berperan sebagai pembaharu dan perekat persatuan dan kesatuan bangsa.

3. Memantapkan sikap dan semangat pengabdian yang berorientasi pada pelayanan, pengayoman, pemberdayaan masyarakat.

Menurut Suwatno (2013), tujuan diklat antara lain:

1. Produktivitas Kerja

Produktivitas kerja pegawai yang tinggi dalam suatu organisasi dapat meningkatkan kualitas maupun kuantitas produksi.

2. Moral Pegawai

Moral pegawai sangat penting bagi suatu lembaga, karena dengan moral pegawai yang baik maka setiap hasil pekerjaan sesuai dengan apa yang diinginkan organisasi.

3. Karier

Persyaratan suatu jabatan menitikberatkan pada syarat-syarat perseorangan yang diperlukan untuk mencapau hasil pekerjaan yang lebih baik.

4. Kepemimpinan

Suatu lembaga membutuhkan seorang pemimpin yang cakap, dimana dia harus mampu mengelola segala kegiatan dan aktivitas yang dimana dia harus mampu mengelola segala kegiatan dan aktivitas yang ada dalam lembaga/organisasi.

\section{Kompensasi}

Dengan meningkatkan keterampilan dan kemampuan yang dimiliki oleh seorang pegawai, akan meningkatkan efektivias dan efisiensi pekerjaan, sehingga tujuan dari lembaga akan tercapai.

\section{Manfaat Pelatihan}

Adapun manfaat dan dampak yang diharapkan dari penyelenggaraan pelatihan menurut Rivai (2014), antara lain:

1. Melalui pendidikan dan pelatihan, variabel pengenalan, pencapaian prestasi, partumbuhan, tanggungjawab dan kemajuan dapat diinternalisasi dan dilaksanakan.
2. Membantu pegawai mengatasi stres, tekanan, frusasi, dan konflik.

3. Memberikan informasi prihal meningkatnya pengetahuan kepemimpinan, keterampilan komunikasi dan sikap.

4. Membantu pengembangan keterampilan mendengar, bicara dan menulis dengan latihan.

5. Membantu pegawai membuat keputusan dan pemecahan masalah yang lebih efektif.

6. Meningkatkan kepuasan kerja \& pengakuan.

7. Membantu menghilangkan rasa takut melaksanakan tugas baru.

8. Meningkatkan keterampilan interpersonal

Dari uraian di atas dapat di simpulkan

bahwa pendidikan dan pelatihan memiliki peranan yang sangat penting dalam suatu lembaga/organisasi, di mana dengan adanya pendidikan dan pelatihan dapat meningkatkan pengetahuan dan keterampilan yang di miliki oleh pegawai, dengan adanya pendidikan dan pelatihan pegawai terbantu mengerjakan pekerjaan yang ada, sehingga pegawai tidak menghiraukan tugas dan tanggung jawab yang diberikan karena adanya pendidikan dan pelatihan yang sering di ikuti, dan setiap tugas yang di berikan dapat di kerjakan dengan tepat waktu, rapi dan baik.

\section{Indikator Pelatihan}

Menurut Mangkunegara (2010), mengemukakan bahwa terdapat beberapa indikator dalam pelatihan:

\section{Instruktur}

Mengingatkan pelatihan berorientasi pada peningkatan skill, maka para pelatih yang dipilih untuk memberikan materi yang memiliki kualifikasi yang memadai sesuai bidangnya, personal dan kompeten, selain itu, pendidikan instruktur pun harus benarbenar baik untuk melakukan pelatihan.

2. Peserta

Peserta pelatihan tentunya harus diseleksi berdasarkan persyaratan tertentu dan kualifikasi yang sesuai, selain itu peserta juga harus memiliki semangat yang tinggi untuk mengikuti pelatihan.

3. Materi

Pelatihan sumber daya manusia merupakan materi atau kurikulum yang sesuai dengan 
tujuan pelatihan sumber daya manusia yang hendak dicapai oleh Kantor Desa Pinang Banjar Kecamatan Sungai Lilin dan materi pelatihan pun harus update agar peserta dapat memahami masalah yang terjadi pada kondisi sekarang.

4. Metode

Metode pelatihan akan lebih menjamin berlangsungan kegiatan pelatihan sumber daya manusia yang efektif apabila sesuai dengan jenis \& komponen peserta pelatihan.

Menurut pendapat Simamora (2006), latihan atau training dimaksudkan untuk memperbaiki penguasaan berbagal ketrampilan dan teknik pelaksanaan kerja tertentu, terinci dan rutin.Latihan rnenyiapkan para pegawai (tenaga kerja) untuk melakukan pekerjaanpekerjaan sekarang. Adapun Indikatorindikator pelatihan adalah :

1. Tujuan

Pelatihan merupakan tujuan yang ditetapkan, khususnya terkait dengan penyusunan rencana aksi dan penetapan sasaran, serta hasil yang diharapkan dari pelatihan yang akan diselenggarakan.

2. Sasaran.

Sasaran pelatihan harus ditentukan dengan kriteria yang terinci dan terukur.

3. Pelatih

Mengingat pelatihan umumnya berorientasi pada peningkatan skill, maka para pelatih yang dipilih untuk memberikan materi pelatihan harus memilih kualifikasi yang memadai sesuai bidangnya,perfessional, dan kompeten.

4. Materi

Pelatihan memerlukan materi atau kurikulum yang sesuai dengan tujuan pelatihan yang hendak dicapai.

5. Metode

Metode pelatihan menjamin berlangsungnya kegiatan pelatihan yang efektif apabila sesuai dengan jenis materi dan kemampuan peserta

6. Peserta Pelatihan

Peserta pelatihan tentunya harus diseleksi berdasarkan persyaratan tertentu dan kualifikasi yang sesuai.

\section{Pengertian Kinerja Pegawai}

Suatu organisasi, baik organisasi pemerintahan maupun organisasi swasta untuk mencapai tujuan tentunya membutuhkan dukungan dari sumber daya manusia.Sumber daya manusia yang baik dapat dilihat dari kinerjanya.Moeheriono (2012), menyatakan bahwa kinerja atau performance merupakan gambaran mengenai tingkat pencapaian pelaksanaan suatu program kegiatan atau kebijakan dalam mewujudkan sasaran, tujuan, visi dan misi organisasi dituangkan melalui perencanaan strategis suatu organisasi.Menurut pendapat Moeheriono (2012),kinerja merupakan sebuah penggambaran mengenai tingkat pencapaian pelaksanaan suatu program kegiatan atau kebijakan dalam mewujudkan sasaran, tujuan, visi, dan misi organisasi yang dituangkan dalam suatu perencanaan strategis suatu organisasi.

Kinerja merupakan gambaran tingkat pencapaian pegawai dalam mewujudkan tujuan suatu organisasi.Agar mempunyai kinerja yang baik, seseorang harus mempunyai keinginan yang tinggi untuk mengerjakan serta mengetahui pekerjaannya. Definisi lain yang dikemukakan oleh Nawawi (2006), kinerja dikatakan tinggi apabila suatu target dapat diselesaikan pada waktu yang tepat atau tidak melampaui batas waktu yang disediakan. Kinerja menjadi rendah apabila diselesaikan melampaui batas waktu yang disediakan atau sama sekali tidak terselesaikan. Kinerja merupakan hasil kerja dari seorang pegawai sesuai tanggung jawabnya dalam melaksanakan tugas sesuai dengan waktu yang telah ditentukan. Setiap organisasi akan berusaha untuk meningkatkan kinerja pegawai dalam mencapai tujuan yang telah ditetapkan, karena keberhasilan suatu organisasi salah satunya dipengaruhi oleh kinerja pegawai. Menurut Fahmi (2010), kinerja adalah hasil yang diperoleh oleh sutau organisasi baik organisasi tersebut bersifat profit oriented dan non profit oriented yang dihasilkan selama satu periode waktu.

Menurut Wibowo (2010), kinerja adalah nilai serangkaian perilaku pekerja yang 
memberikan kontribusi, baik secara positif atau negatif, pada penyelesaiaan tujuan organisasi. Kinerja organisasi juga ditunjukan oleh bagaimana berlangsungnya kegiatan untuk mencapai tujuan tersebut. Didalam proses pelaksanaan aktivitas harus selalu dilakukan monitoring, penilaian, dan review atau peninjauan ulang terhadap kinerja sumber daya manusia. Melalui monitoring dilakukan pengukuran dan penilaian kinerja secara periodik untuk mengetahui pencapaian kemajuan kinerja dilakukan prediksi apakah terjadi deviasi pelaksanaan terhadap rencana yang dapat mengganggu pencapaian tujuan.

Menurut Hasibuan (2006), kinerja mengacu pada prestasi pegawai yang diukur berdasarkan standar yang ditetapkan organisasi atau Kantor Desa Pinang Banjar Kecamatan Sungai Lilin. kinerja adalah suatu hasil kerja yang dicapai oleh seseorang dalam melaksanakan tugas-tugas yang dibebankan kepadanya yang didasarkan atas kecakapan, pengalaman, dan kesungguhan serta waktu.

Berdasarkan pengertian di atas, dapat ditarik kesimpulan bahwa kinerja pegawai adalah hasil kerja yang dicapai oleh pegawai dalam suatu organisasi sesuai dengan wewenang dan tanggung jawab masing-masing dan diselesaikan dengan waktu yang telah ditentukan, kecakapan pegawai, pengalaman, kualitas, dan kuantitas guna mencapai visi, misi, dan tujuan organisasi. Kinerja dapat dikatakan tinggi apabila target dapat diselesaikan dengan waktu yang tepat, sedangkan kinerja dikatakan rendah apabila diselesaikan melampaui batas waktu yang telah ditentukan.

\section{Faktor-Faktor Yang Mepengaruhi Kinerja Pegawai}

Kinerja merupakan gambaran mengenai tingkat pencapaian pegawai dalam melaksanakan suatu kegiatan dalam sebuah organisasi.Kinerja seorang pegawai tidak selalu berada dalam kondisi yang baik, kinerja pegawai dipengaruhi oleh beberapa hal.Faktorfaktor yang dapat mempengaruhi kinerja seorang pegawai dalam melaksanakan tugas dan tanggung jawabnya. Menurut Nawawi
(2006), kinerja dipengaruhi oleh tiga faktor yang terdiri dari:

1. Minat dalam bekerja

2. Penerimaan delegasi tugas, dan

3. Peran dan tingkat motivasi seorang pekerja

Kinerja dalam menjalankan fungsinya tidak berdiri sendiri, tetapi berhubungan dengan faktor-faktor yang mempengaruhinya, kinerja dapat dipengaruhi oleh faktor internal dan faktor eksternal. Menurut Soesilo (2005), mengatakan bahwa kinerja dipengaruhi oleh lima faktor antara lain yaitu:

1. Struktur organisasi sebagai hubungan internal yang berkaitan dengan fungsi yang menjelaskan aktivitas organisasi.

2. Kebijakan pengelolaan, berupa visi dan misi organisasi.

3. Sumber daya manusia, yang berkaitan dengan kualitas pegawai untuk bekerja dan berkarya secara optimal.

4. Sistem informasi manajemen, yang berhubungan dengan pengelolaan database untuk dipergunakan dalam mempertinggi kinerja organisasi.

5. Sarana dan prasarana yang dimiliki, yang berhubungan dengan penggunaan teknologi bagi penyelenggaraan organisasi pada setiap aktivitas organisasi.

Dalam suatu organisasi, antara pegawai yang satu dengan pegawai yang lain mempunyai kinerja yang berbeda-beda. Perbedaan kinerja antara satu pegawai dengan pegawai yang lain tentu ada faktor penyebabnya. Pimpinan organisasi sangat menyadari adanya perbedaan prestasi kerja antara satu pegawai dengan pegawai yang lain yang berada di bawah pengawasannya. Secara garis besar perbedaan disebabkan oleh faktorfaktor yang mempengaruhinya. Mangkunegara (2007), membedakan menjadi dua faktor yang mempengaruhi pencapaian kinerja, yaitu:

1. Faktor kemampuan

Secara psikologis, kemampuan terdiri dari kemampuan potensi (IQ) dan kemampuan reality (knowledge dan skill). Artinya pimpinan dan pegawai yang memiliki IQ di atas rata-rata (IQ 110-120) apalagi IQ superior, very superior, gifted dan genius dengan pendidikan yang memadai untuk 
jabatannya dan terampil dalam mengerjakan pekerjaan sehari-hari, maka akan lebih mudah mencapai kinerja maksimal.

2. Faktor motivasi

Motivasi diartikan suatu sikap pimpinan dan pegawai terhadap situasi kerja (situation) di lingkungan organisasinya. Mereka yang bersikap positif (pro) terhadap situasi kerjanya akan menunjukkan motivasi kerja tinggi dan sebaliknya jika mereka bersikap negatif (kontra) terhadap situasi kerjanya akan menunjukkan motivasi kerja yang rendah. Situasi kerja yang dimaksud adalah: hubungan kerja, fasilitas kerja, iklim kerja, kebijakan pimpinan, pola kepemimpinan kerja dan kondisi kerja.

Berdasarkan pendapat di atas, dapat disimpulkan bahwa ada beberapa faktor yang mempengaruhi kinerja pegawai. Faktor inidapat dibedakan menjadi dua yaitu:

1. Faktor internal adalah faktor yang berasal dari dalam diri pegawai antara lain minat dan motivasi dalam bekerja, pengetahuan, pengalaman, kepribadian dan kemampuan.

2. Faktor eksternal adalah faktor yang berasal dari luar diri pegawai yaitu dari organisasi di mana pegawai bekerja, antara lain imbalan, sarana dan prasarana, sistem informasi manajeman, kebijakan organisasi, dan tugas yang diberikan.

\section{Standar Kinerja Pegawai}

Suatu organisasi perlu menetapkan standar kinerja untuk pegawainya agar organisasi mempunyai tolok ukur mengenai kemampuan pegawai terkait tugas dan tanggung jawab yang telah diberikan. Ma'ruf (2014), menyatakan bahwa, Standar kinerja merupakan tingkat kinerja yang diharapkan dalam suatu organisasi, dan merupakan pembanding atau tujuan atau target tergantung pada pendekatan yang diambil. Standar kinerja yang baik harus realistis, dapat diukur dan mudah dipahami dengan jelas sehingga bermanfaat baik bagi organisasi maupun para pegawai.Untuk menetapkan tingkat kinerja pegawai, dibutuhkan penilaian kinerja.Penilaian kinerja yang adil membutuhkan standar.Standar kinerja digunakan sebagai perbandingan antara tujuan dengan kinerja pegawai. Wibowo (2010), menyatakan bahwa standar kinerja menjelaskan apa yang diharapkan manajer dari pekerja sehingga harus dipahami pekerja. Klarifikasi tentang apa yang diharapkan merupakan hal yang penting untuk memberi pedoman perilaku pekerja dan dipergunakan sebagai dasar untuk penilaian. Standar kinerja merupakan tolok ukur terhadap mana kinerja diukur agar efektif.Dengan demikian, standar kinerja merupakan pernya-taan tentang situasi yang terjadi ketika sebuah pekerjaan dilakukan secara efektif. Standar kinerja dipakai apabila tidak mungkin menetapkan target berdasarkan waktu. Pekerja juga harus memahamiwujud kinerja yang baik.

Standar kinerja terfokus pada seberapa baik tugas akan dilaksanakan. Minimal sebuah standar kinerja harus berisi dua jenis informasi dasar tentang apa yang harus dilakukan dan seberapa baik harus melakukannya. Nawawi (2006) menyatakan Standar kinerja pada dasarnya berisi ukuran atau tolok ukur mengenai efektivitas, efisiensi, produktivitas pelaksanaan pekerjaan/jabatan menggambarkan tingkat pemahaman, tingkat kemampuan seorang pekerja/pegawai dalam melaksanakan tugas pokoknya dilingkungan organisasi/organisasi. Lebih lanjut dijelaskan oleh Nawawi (2006), bahwa standar kinerja memiliki beberapa ciri berikut:

1. Berisi kriteria pelaksanaan pekerjaan (kinerja) yang terbaik sebagai pembanding terhadap pelaksanaan pekerjaan oleh pekerja/pegawai, yang perumusannya harus konsisten dengan deskripsi dan spesifikasi pekerjaan, meskipun selalu berubah dan berkembang menyesuaikan dinamika kerja.

2. Berisi aspek-aspek yang jelas dan dapat diukur dari pelaksanaan suatu pekerjaan, baik yang bersifat kuntitatif maupun kualitatif. Standar kinerja kuantitatif dengan tolok ukur berbentuk bilangan, antara lain berupa target jumlah atau target waktu dalam penyelesaian produk berupa barang/target yang dapat dihitung frekuensinya sebagai tingkat produktivitas dalam bekerja. Sedangkan standar kinerja kualitatif dengan tolok ukur mutu atau kualitas, efisiensi, efektivitas pelaksanaan 
pekerjaan. Tolok ukur ini antara lain berupa kriteria tingkkat efektivitas, kemampuan pemecahan masalah dan pengambilan keputusan, kemampuan kepemimpinan atau manajerial, ketepatan penggunaan waktu, penghematan bahan, penghematan pembiayaan, ketelitian kerja.

3. Standar kinerja harus memiliki kriteria yang jelas agar penilai bebas dari bias dalam menilai, dan bebas pula dari kemungkinan pekerja atau pegawai yang dinilai merasa diperlakukan tidak adil oleh organisasi atau organisasi.

Berdasarkan pendapat di atas, dapat disimpulkan bahwa standar kinerja pegawai adalah tolok ukur minimal kinerja yang ada di sebuah organisasi sebagai pembanding antara tujuan/target dengan hasil yang dicapai oleh pegawai.Standar kinerja dibuat berdasarkan kriteria-kriteria yang realistis dan dapat diukur. Standar kinerja berisi kriteria pelaksanaan pekerjaan, aspek-aspek yang jelas daan dapat diukur dari pelaksanaan sutau pekerjaan, dan harus memiliki kriteria yang jelas agar penilai bebas dari bias dalam menilai.

\section{Manfaat Penilaian Kinerja Pegawai}

Penilaian kinerja pegawai tidak sematamata hanya menilai pegawai saja, banyak manfaat yang didapatkan dengan adanya penilaian kinerja pegawai salah satunya sebagai bahan guna mengembangkan suatu organisasi secara efektif dan efisien. Fahmi (2010), menyatakan bahwa ada banyak manfaat dengan dilakukannya penilaian kinerja, yaitu:

1. Mengelola operasi organisasi secara efektif dan efisien melalui permotivasian pegawai secara maksimum.

2. Membantu pengambilan keputusan yang bersangkutan dengan pegawai, seperti promosi, transfer, dan pemberhentian.

3. Mengidentifikasikan kebutuhan pelatihan dan pengembangan pegawai dan untuk menyediakan kriteria selesi dan evaluasi program pelatihan pegawai.

4. Menyediakan umpan balik bagi pegawai mengenai bagaimana atasan mereka menilai kinerja mereka.

5. Menyediakan suatu dasar bagi distribusi penghargaan. Pengukuran kinerja pada dasarnya telah diterapkan dihampir seluruh organisasi. Namun pengukuran kinerja seringkali hanya menjadi sebuah aktifitas tanpa adanya tindak lanjut dari hasil pengukuran yang didapatkan.

Menurut Bangun (2012), bagi suatu organisasi penilaian kinerja memiliki berbagai manfaat antara lain, evaluasi antar individu dalam organisasi, pengembangan dalam diri individu, pemeliharaan sistem, dokumentasi.

1. Evaluasi antar individu dalam organisasi

Penilaian kinerja bertujuan untuk menilai kinerja setiap individu dalam organisasi dalam menentukan jumlah dan jenis kompensasi yang merupakan hak bagi setiap individu dalam organisasi.

2. Pengembangan dari diri setiap individu dalam organisasi

Penilaian kinerja pada tujuan ini bermanfaat untuk pengembangan pegawai yang memiliki kinerja rendah yang membutuhkan pengembangan baik melalui pendidikan formal maupun pelatihan.

3. Pemeliharaan system

Berbagai sistem yang ada dalam organisasi memiliki sub sistem yang saling berkaitan antara satu sub sistem sengan sub sistem lainnya. Oleh karena itu perlu dipelihara dengan baik.

4. Dokumentasi

Penilaian kinerja memberi manfaat sebagai dasar tindak lanjut dalam posisi pekerjaan pegawai di masa akan datang. Hal ini berkaitan dengan pengambilan keputusan.

Penilaian kinerja sebagai sumber informasi bagi penentuan kebijakan strategi SDM organisasi di masa depan, sebagai suatu alat evaluasi kinerja serta sebagai alat untuk memetakan potensi dari pegawai organisasi. Sedarmayanti (2014), menyatakan bahwa manfaat dari penilaian kinerja adalah :

1. Meningkatkan prestasi kerja

Dengan adanya penilaian, baik pimpinan maupun pegawai memperoleh umpan balik dan mereka dapat memperbaiki pekerjaan/prestasinya.

2. Memberi kesempatan kerja yang adil

Penilaian akurat dapat menjamin pegawai memperoleh kesempatan menempati sisi pekerjaan sesuai kemampuannya. 
3. Kebutuhan pelatihan dan pengembangan. Penilaian kinerjaakanmampu mendeteksi pegawai yang memiliki kemampuan rendah sehingga memungkinkan adanya program pelatihan untuk meningkatkan kemampuan mereka.

4. Penyesuaian kompensasi

Melalui penilaian, pimpinan bisa mengambil keputusan dalam menentukan perbaikan pemberian kompensasi, dan sebagainya.

5. Keputusan promosi dan demosi

Hasil penilaian kinerja dapat digunakan sebagai dasar pengambilan keputusan untuk promosi atau demosi pegawai.

6. Mendiagnosis kesalahan desain pekerjaan

Kinerja yang buruk merupakan suatu tanda kesalahan dalam desain pekerjaan.Penilaian kinerja dapat membantu mendiagnosis kesalahan.

7. Menilai proses rekruitmen dan seleksi

Kinerja pegawai baru dapat mencerminkan adanya penyimpangan proses rekruitmen dan seleksi.

Dari beberapa manfaat penilaian kinerja yang telah dipaparkan oleh para ahli, dapat disimpulkan bahwa penilaian kinerja memiliki manfaat bagi pegawai maupun organisasi.Manfaat penilaian kinerja bagi pegawai yaitu untuk menigkatkan prestasi kerja dan sebagai evaluasi antar individu.Manfaat penilaian kinerja bagi organisasi yaitu sebagai bahan pengambilan keputusan, sebagai sarana meng-identifikasikan kebutuhan pelatihan, sebagai penyesuaian kompensasi dan penghargaan.

\section{Pengukuran Kinerja}

Pencapaian suatu organisasi perlu diukur, karena pengukuran merupakan aspek kunci dari manajemen kinerja.Sehingga pengukuran kinerja perlu ditetapkan, pengukuran kinerja sangat bergantung dengan indikator kinerja yang digunakan.Pengukuran kinerja menurut Moeheriono (2012), pengukuran kinerja adalahperangkat manajemen yang digunakan untuk meningkatkan kualitas pengambilan keputusan serta akuntabilitas, serta untuk menilai pen-capaian tujuan dan sasaran (goal sand objectives). Sedangkan menurut
Moeheriono (2012), pengukuran kinerja (performance measurement) mempunyai pengertian suatu proses penilaian tentang kemajuan pekerjaan terhadap tujuan dan sasaran dalam pengelolaan sumber daya manusia untuk menghasilkan barang dan jasa, termasuk informasi atas efisiensi serta efektivitas tindakan dalam mencapai tujuan organisasi.

Pengukuran kinerja merupakan proses penilaian tentang kemajuan pekerjaan yang dicapai oleh seseorang atau kelompok orang dalam suatu organisasi. Pengukuran kinerja digunakan sebagai dasar untuk menilai keberhasilan dan kegagalan pelaksanaan suatu kegiatan sesuai dengan tujuan yang telah ditetapkan. Junaidi (2002), menyatakan bahwa pengukuran kinerja merupakan proses mencatat serta mengukur pencapaian pelaksanaan kegiatan dalam arah pencapaian misi melalui hasil-hasil yang ditampilkan berupa produk, jasa, ataupun proses. Pengukuran kinerja dapat dijadikan sebagai ukuran keberhasilan sutau organisasi dalam kurun waktu tertentu dan hasil pengukuran kinerja dapat dijadikan sebagai masukan untuk perbaikan.

Dari beberapa pengertian pengukuran kinerja maka disimpulkan bahwa pengukuran kinerja merupakan sutau sistem yang bertujuan untuk membantu manajer organisasi menilai pencapaian suatu tujuan melalui alat ukur.Hasil pengukuran tersebut dapat digunakan sebagai umpan balik yang memberikan informasi tentang pelaksanaan suatu kegiatan.

\section{Indikator Kinerja Pegawai}

Dalam melaksanakan penilaian kinerja pegawai, organisasi sebaiknya menetapkan indikator-indikator kinerja sebagai standar pengukuran kinerja. Moeheriono (2012), menyatakan bahwa kinerja diukur berdasarkan ukuran indikator kinerja yang dikelompokkan kedalam enam kategori yaitu:

1. Efektif, indikator ini mengukur derajat kesesuaian output yang dihasilkan dalam mencapai sesuatu yang diinginkan.

2. Efisien, indikator ini mengukur derajat kesesuaian proses menghasilkan output 
dengan menggunakan biaya serendah mungkin.

3. Kualitas, indikator ini mengukur derajat kesesuaian antara kualiatas produk atau jasa yang dihasilkan dengan kebutuhan dan harapan konsumen.

4. Ketepatan waktu, indikator ini mengukur apakah pekerjaan telah diselesaikan secara benar dan tepat waktu.

5. Produktivitas, indikator ini mengukur tingkat produktivitas suatu organisasi.

6. Keselamatan, indikator ini mengukur kesehatan organisasi secara keseluruhan serta lingkungan kerja para pegawainya ditinjau dari aspek keselamatan

\section{Kerangka Pemikiran}

Berdasarkan latar belakang diatas dan tinjauan pustaka yang telah dipaparkan sebelumnya, maka sebagai kerangka pikir penelitian ini adalah sebagai berikut :

\begin{tabular}{|l|l|}
\hline \multicolumn{1}{|l|}{ Pelatihan $(\mathbf{X})$} & \multicolumn{1}{|}{ Kinerja Pegawai (Y) } \\
Indikator: & \multicolumn{1}{|c|}{ Indikator: } \\
1. Tujuan & 1. Efektif \\
2. Sasaran & 2. Efisien \\
3. Pelatih & 3. Kualitas \\
4. Materi & 4. Ketepatan Waktu \\
5. Metode & 5. Produktivitas \\
6. Peserta Pelatih & 6. Keselamatan \\
\hline
\end{tabular}

\section{Gambar 1 \\ Kerangka Pemikiran}

Berdasarkan gambar diatas, dapat dijelaskan bahwa pelatihan kerja (X) di sebuah kantor desa terjadi karena didalam suatu kantor desa terdiri dari orang-orang yang mempunyai latar belakang, sikap, maupun pandangan yang berbeda satu sama lain. Pelatian kerja yang baik dapat meningkatkan kinerja. Sebaliknya pelatihan kerja tidak memadai akan dapat menurunkan kinerja dan akhirnya akan dapat menurunkan kinerja pegawai.

\section{Hipotesis}

Adapun hipotesis yang diajukan pada penelitian ini adalah diduga ada Pengaruh pelatihan terhadap kinerja perangkat desa pada Desa Pinang Banjar Kecamatan Sungai Lilin.

\section{Metodologi Penelitian Jenis dan Sumber Data}

Jenis data yang digunakan dalam penelitian iniadalah Data Antar Wilayah (Cross Section).Sedangkan sumber data yang digunakan dalam penelitian ini berupa data sekunder.Data Primer dan Data Sekunder bersumber dari Data perangkat desa Pinang Banjar Kecamatan Sungai Lilin Kabupaten Musi Banyuasin.

\section{Teknik Pengumpulan Data}

Adapun teknik pengumpulan data yang digunakan dalam penelitian ini, adalah sebagai berikut :

1. Kepustakaan (library research)

Teknik pengumpulan data dengan cara membaca, mempelajari, mengutip, serta membandingkan informasi yang ada dalam buku-buku yang berkaitan dengan permasalahan yang akan dibahas.

2. Wawancara (interview)

Dengan mengajukan pertanyaan-pertanyaan yang telah dipersiapkan terlebih dahulu secara lisan mengenai masalah-masalah yang akan diteliti kepada perangkat desa Pinang Banjar Kecamatan Sungai Lilin Kabupaten Musi Banyuasin.

3. Observasi (Observation)

Untuk mendapatkan data dan informasi yang dibutuhkan dengan permasalahan dalam penelitian.Penulis melakukan observasi pada perangkat desa Pinang Banjar Kecamatan Sungai Lilin Kabupaten Musi Banyuasin.

4. Metode dokumentasi adalah mencari data yang berkaitan dengan variabel yang berupa catatan, buku, surat kabar, majalah, prasasti, notulen rapat, agenda dan sebagainya yang berkaitan dengan kajian penelitian.

\section{Definisi OperasionalisasiDan Pengukuran} Variabel 
Dalam penelitian ini dianalisis ada atau tidaknyapengaruh antara dua variabel yaitu:

1. Pelatihan sebagai variabel independen (X).pelatihan merupakan proses pembelajaran yang melibatkan perolehan keahlian, konsep, peraturan, atau sikap untuk meningkatkan kinerja pegawai.

2. Kinerja Pegawai sebagai variabel dependen (Y) yang merupakan gambaran mengenai tingkat pencapaian pelaksanaan suatu program kegiatan atau kebijakan dalam mewujudkan sasaran, tujuan, visi dan misi organisasi yang dituangkan melalui perencanaan strategis suatu organisasi. Selain itu kinerja seseorang dipengaruhi oleh tingkat pendidikan, inisiatif, pengalaman kerja, dan motivasi pegawai.

Adapun tabel pengukuran variabel sebagai berikut :

Tabel 1.Definisi Operasionalisasi Variabel

\begin{tabular}{|c|l|c|c|}
\hline Variabel & \multicolumn{1}{|c|}{$\begin{array}{c}\text { Indikator } \\
\text { Variabel }\end{array}$} & $\begin{array}{c}\text { Item } \\
\text { Pertanyaan }\end{array}$ & $\begin{array}{c}\text { Skala } \\
\text { Pengukuran }\end{array}$ \\
\hline \multirow{5}{*}{ Pelatihan } & 1. Tujuan & $1-2$ & \\
$\left(\mathrm{X}_{1}\right)$ & 2. Sasaran & $3-4$ & \\
& 3. Pelatih & $5-6$ & \\
& 4. Materi & $7-8$ & Skala Likert \\
& 5. Metode & $9-10$ & \\
& 6. Peserta & $11-12$ & \\
\hline \multirow{5}{*}{ Kinerja } & Pelatihan & & \\
Pegawai & 2. Efektif & 1 & \\
(Y) & 3. Kualitas & $2-3$ & \\
& 4. Ketepatan & $4-5$ & \multirow{2}{*}{ Skala Likert } \\
& Waktu & $8-7$ & \\
& 5. Produktivitas & 10 & \\
& 6. Keselamatan & & \\
\hline
\end{tabular}

\section{Populasi dan Sampel.}

\section{Populasi.}

Menurut Arikunto (2012), populasi diartikan sebagai keseluruhan dari subjek atau objek penelitian. Jika seorang peneliti ingin meneliti semua elemen yang terdapatdi wilayah penelitian, maka penelitian merupakan penelitian populasi.Pada penelitian, penulis menjadikan perangkat desa Pinang Banjar sebagai populasi yang sampai dengan saat ini totalnya berjumlah 56 orang.

\section{Sampel.}

Menurut Sugiyono (2013), Sampel adalah bagian dari jumlah dan karakteristik yang dimiliki oleh populasi tersebut. Dengan demikian sampel adalah sebagian dari populasi yang karakteristiknya hendak diselidiki, dan bisa mewakili keseluruhan populasinya sehingga jumlahnya lebih sedikit dari populasi. Menurut Arikunto (2012), sampel adalah sebagian atau wakil populasi yang diteliti. Dalam penelitian ini Sampel diambil dengan menggunakan teknik sampling jenuh.Sampel dalam penelitian ini adalah seluruh populasi dari penelitian ini yaitu seluruh seluruh pegawai Kantor Desa Pinang Banjar yang berjumlah 56 orang.

\section{Teknik Analisis Data}

Teknikanalisisdataadalahsuatumetode atau cara untuk mengolah sebuah data menjadi informasi sehingga karakteristik data tersebut menjadi mudah untuk dipahami dan juga bermanfaat untuk menemukan solusi permasalahan, yang tertutama adalah masalahyang tentang sebuah penelitian. Atau analisis data juga bisa diartikan sebagai kegiatan yang dilakukan untuk merubah data hasil dari sebuah penelitian menjadi informasi yang nantinya bisa dipergunakan untuk mengambil sebuah kesimpulan. Adapun tahaptahap analisis data yang digunakan adalah sebagai berikut :

\section{Uji Validitas}

Arikunto (2012), menjelaskan validitas adalah keadaan yang menggambarkan tingkat instrumen bersangkutan yang dapat mengukur apa yang akan diukur menggunakan kuesioner. Kuesioner dikatakan valid jika pertanyaan pada kuesioner mampu untuk mengungkapkan sesuatu yang akan diukur oleh kuesioner tersebut. Dalam hal ini digunakan beberapa butir pertanyaan yang dapat secara tepat mengungkapkan variabel yang diukur tersebut. Untuk mengukur tingkat validitas dapat dilakukan dengan cara mengkorelasikan antara skor butir pertanyaan dengan total skor konstruk atau variabel. Pengujian menggunakan uji dua sisi dengan taraf signifikansi 0,05. Kriteria pengujian adalah sebagai berikut :

$>$ Jika $r_{\text {hitung }} \geq r_{\text {tabel }}$ (uji 2 sisi dengan sig 0,05) maka instrumen atau item-item pertanyaan berkolerasi signifikan terhadap skor total (dinyatakan valid). 
Jika $r_{\text {hitung }} \leq r_{\text {tabel }}$ (uji 2 sisi dengan sig 0,05) maka instrumen atau item-item pertanyaan tidak berkolerasi signifikan terhadap skor total (dinyatakan tidak valid).

Menurut Bandur (2013), uji validitas dilakuan dengan membandingkan nilai $\mathrm{r}_{\text {hitung }}$ dengan $r_{\text {tabel }}$ untuk tingkat signifikansi 5 persen dari degree of freedom $(\mathrm{df})=\mathrm{n}-2$, dalam hal inin adalah jumlah sampel. Jika $r_{\text {hitung }}>r_{\text {tabel }}$ maka pertanyaan atau indikator tersebut dinyatakan valid, demikian sebaliknya bila $\mathrm{r}_{\text {hitung }}<\mathrm{r}_{\text {tabel }}$ maka pertanyaan atau indikator tersebut dinyatakan tidak valid.

\section{Uji Reliabilitas}

Uji reliabilitas digunakanuntuk mengetahui adanya konsistensi alat ukur dalam penggunaannya. Dengan kata lain alat ukur tersebut mempunyai hasil yang presisi apabila digunakan berkali-kali pada waktu yang berbeda. Sugiyono (2013) menyatakan jika KoefisienCronbach's Alphakurang dari 0,60 dianggap buruk, kehandalan dalam kisaran 0,70 bisa diterima dan lebih dari 0.80 adalah baik. Untuk menguji reliabilitas instrumen dalam penelitian ini yaitu menggunakan uji Cronbach's Alpha dimana teknik Cronbach's Alpha dilakukan untuk jenis data essay.

\section{Regresi Linier Sederhana}

Untuk mengetahui pengaruh pelatihan terhadap kinerja digunakan teknik analisis regresi linier sederhana. Menurut Sugiyono (2013), analisis regresi linier sederhana digunakan untuk meramalkan bagaimana keadaan (naik turunnya) variabel dependen, bila dua atau lebih variabel independen sebagai faktor predictor (dinaik turunkan nilainya). Analisis ini menggunakan rumus persamaan berikut:

$$
\mathbf{Y}=\boldsymbol{\alpha}+\boldsymbol{\beta} \mathbf{X}+\mathbf{e}
$$

Dimana:

$\mathrm{Y}=$ Subyek dalam variabel dependen yang diprediksikan dalam hal kinerja pegawai.

$\alpha=$ Y bila $\mathrm{X}=0$ (harga konstan)

$\beta=$ Angka arah atau koefisien regresi, yang menunjukkan angka peningkatan ataupun penurunan variabel independen.

$\mathrm{X}=$ Variabel independen, yaitu Pelatihan

\section{Uji Korelasi}

Analisis korelasi yang digunakan dalam penelitian adalah analisis korelasi sederhana. Analisis korelasi sederhana (Bivariate Correlation) digunakan untuk mengetahui keeratan hubungan antara dua variabel yaitu variabel bebas $(\mathrm{X})$ yaitu tingkat pendidikan dan pelatihan dengan variabel terikat $(\mathrm{Y})$ yaitu kinerja serta untuk mengetahui arah hubungan yang terjadi. Dalam penelitian ini perhitungan korelasi sederhana menggunakan bantuan program SPSS versi 20. Menurut Sugiyono (2013), pedoman digunakan untuk memberikan inteprestasi koefisien korelasi sebagai berikut :

a. Jika Koefisien Korelasi 0,01 sampai 0,199 hubungannya sangat rendah.

b. Jika Koefisien Korelasi 0,20 sampai 0,399 hubungannya rendah.

c. Jika Koefisien Korelasi 0,40 sampai 0,599 hubungannya sedang

d. Jika Koefisien Korelasi 0,60 sampai 0,799 hubungannya kuat.

e. Jika Koefisien Korelasi 0,80 sampai 0,99 sangat kuat.

\section{Koefisien Determinan $\left(R^{2}\right)$}

Analisis koefisien determinasi $\left(\mathrm{R}^{2}\right)$ dalam regresi linear sederhana digunakan untuk mengetahui persentase sumbangan pengaruh variabel independen $(\mathrm{X})$ terhadap variabel dependen (Y) Nilai Koefisien Determinasi adalah antara nol dan satu.Nilai $\mathrm{R}^{2}$ yang kecil berarti variasi variabel Dependen yang sangat terbatas.dan nilai yang mendekati 1 (satu) berarti variabel-variabel independen sudah dapat memberi semua informasi yang dibutuhkan untuk memprediksi variabel Dependen. Secara umum koefisien determinasi untuk data silang (Crossection) relatif rendah karena adanya variasi yang besar antara masing-masing pengamatan, sedangkan untuk data runtut waktu (Time Series) biasanya mempunyai data koefisien determinasi yang lebih tinggi dengan rumus $\mathrm{KD}=\mathrm{R}^{2} \mathrm{X} 100 \%$.

\section{Pengujian Hipotesis}

Menurut Ghozali (2016), uji t pada dasarnya menunjukkan seberapa jauh pengaruh satu variabel penjelas atau independen secara individual dalam menerangkan variasi variabel 
Vol. 4 No. 2 Desember 2021, 39-55

dependen. Tujuan uji hipotesis adalah untuk menetapkan suatu dasar sehingga dapat mengumpulkan bukti yang berupa data-data dalam menentukan keputusan apakah menolak atau menerima kebenaran dari pernyataan atau asumsi yang telah dibuat.Berdasarkan latar belakang yang telah penulis uraian diatas, maka hipotesis dalam penelitian ini adalah:

- Jika Nilai Sig. $<0,05$ atau $t_{\text {hitung }}>t_{\text {tabel }}$, maka $\mathrm{H}_{\mathrm{o}}$ ditolak dan $\mathrm{H}_{\mathrm{a}}$ diterima, maka terdapat pengaruh Pelatihan terhadap Kinerja Pegawai pada perangkat desa Pinang Banjar Kecamatan Sungai Lilin Kabupaten Musi Banyuasin.

- Jika Nilai Sig.> 0,05 atau $t_{\text {hitung }} \leq t_{\text {tabel, }}$, maka $\mathrm{H}_{\mathrm{o}}$ diterima dan $\mathrm{H}_{\mathrm{a}}$ ditolak, maka tidak terdapat pengaruh Pelatihan terhadap Kinerja Pegawai pada perangkat desa Pinang Banjar Kecamatan Sungai Lilin Kabupaten Musi Banyuasin.

\section{Hasil Penelitian dan Implementasi Hasil Penelitian}

Variabel Penelitian yang digunakan dalam penelitianadalah variable bebas (Independent) yaitu Pelatihan, variabel terikat (Dependent) yaitu Kinerja Pegawai pada Perangkat desa Pinang Banjar Kecamatan Sungai Lilin Kabupaten Musi Banyuasin.

\section{a. Uji Validitas.}

Pengujian validitas dalam penelitian ini menggunakan program SPSS versi 20. Dengan kriteria pengujian nilai $r_{\text {hitung }}>r_{\text {tabel }}$ dapat dinyatakan valid. Nilai $r_{\text {tabel }}$ yang didapat untuk56 responden dengan tingkat signifikansi $5 \%$ adalah, $\mathrm{Df}=\mathrm{N}-2=56-2=54$, maka nilai $r_{\text {tabel }}$ dengan $\mathrm{DF}=54$, Tingkat Signifikansi 5\% adalah sebesar 0,2632.Adapun hasil uji validitas butir kuesioner tersebut dapat dilihat pada tabel dibawah ini :

\section{Tabel 3.Hasil Uji Validitas}

\begin{tabular}{|c|c|c|c|c|}
\hline No. & $\begin{array}{c}\text { Item } \\
\text { Kuesioner }\end{array}$ & R-Hitung & R-tabel & Keterangan \\
\hline $\mathbf{1 .}$ & $\mathrm{X} 1.1$ & 0,766 & 0,2632 & Valid \\
\hline $\mathbf{2 .}$ & $\mathrm{X} 1.2$ & 0,847 & 0,2632 & Valid \\
\hline 3. & $\mathrm{X} 1.3$ & 0,876 & 0,2632 & Valid \\
\hline $\mathbf{4 .}$ & $\mathrm{X} 1.4$ & 0,790 & 0,2632 & Valid \\
\hline $\mathbf{5 .}$ & $\mathrm{X} 1.5$ & 0,861 & 0,2632 & Valid \\
\hline $\mathbf{6 .}$ & $\mathrm{X} 1.6$ & 0,791 & 0,2632 & Valid \\
\hline $\mathbf{7 .}$ & $\mathrm{X} 1.7$ & 0,786 & 0,2632 & Valid \\
\hline $\mathbf{8 .}$ & $\mathrm{X} 1.8$ & 0,786 & 0,2632 & Valid \\
\hline
\end{tabular}

\begin{tabular}{|c|c|c|c|c|}
\hline 9. & X1.9 & 0,786 & 0,2632 & Valid \\
\hline 10. & X1.10 & 0,786 & 0,2632 & Valid \\
\hline 11. & X1.11 & 0,786 & 0,2632 & Valid \\
\hline $\mathbf{1 2 .}$ & X1.12 & 0,786 & 0,2632 & Valid \\
\hline 13. & Y1.1 & 0,755 & 0,2632 & Valid \\
\hline 14. & Y1.2 & 0,818 & 0,2632 & Valid \\
\hline $\mathbf{1 5 .}$ & Y1.3 & 0,856 & 0,2632 & Valid \\
\hline $\mathbf{1 6 .}$ & Y1.4 & 0,833 & 0,2632 & Valid \\
\hline 17. & Y1.5 & 0,844 & 0,2632 & Valid \\
\hline No. & Item & R-Hitung & R-tabel & Keterangan \\
\hline 18. & Y1.6 & 0,840 & 0,2632 & Valid \\
\hline 19. & Y1.7 & 0,800 & 0,2632 & Valid \\
\hline 20. & Y1.8 & 0,829 & 0,2632 & Valid \\
\hline $\mathbf{2 1 .}$ & Y1.9 & 0,829 & 0,2632 & Valid \\
\hline 22. & Y1.10 & 0,829 & 0,2632 & Valid \\
\hline Sur
\end{tabular}

Sumber :Data Primer (diolah), 2021.

Berdasarkan hasil perhitungan validitas butir kuesioner dapat dilihat dari tabel 3 diatas diketahui bahwa keselurahan butir kuesioner dapat dikatakan valid karena nilai $r_{\text {hitung }}$ (ItemTotalCorrelation) $>\mathrm{r}_{\text {tabel }}$ sebesar 0,2632.

\section{b. Uji Reliabilitas.}

Uji reliabilitas dalam penelitian ini menggunakan program SPSS versi 20. Suatu variabel dapat dikatakan reliabel jika nilai Cronbach's Alpha>0,6. Hasil dari uji reliabilitas yang telah digunakan dapat dilihat berdasarkan tabel 4 berikut ini :

Tabel 4. Hasil Uji Reliabilitas

\begin{tabular}{|l|c|c|}
\hline \multicolumn{1}{|c|}{ Variabel } & $\begin{array}{c}\text { Cronbach's } \\
\text { Alpha }\end{array}$ & Keterangan \\
\hline Pelatihan (X) & 0,650 & Reliabel \\
\hline Kinerja Pegawai (Y) & 0,722 & Reliabel \\
\hline
\end{tabular}

Sumber : Data Primer (diolah), 2021.

Dari tabel diatas diperoleh bahwa nilai cronbach's alpha untuk variabel Pelatihan (X) sebesar 0,650> 0,6 dengan demikian dapat disimpulkan bahwa variabel Pelatihan (X) bernilai reliabel. Untuk variabel Kinerja Pegawai(Y) nilai Cronbach's Alphasebesar 0,722> 0,6, maka dapat disimpulan bahwa variabel Kinerja Pegawai (Y) bernilai reliabel.

\section{c.Uji Regresi Sederhana.}

Bedasarkan hasil dari analisis regresi linear sederhana dengan bantuan program SPSS versi 20 dapat dilihat dibawah ini :

Tabel 5.Nilai Koefisien Regresi 


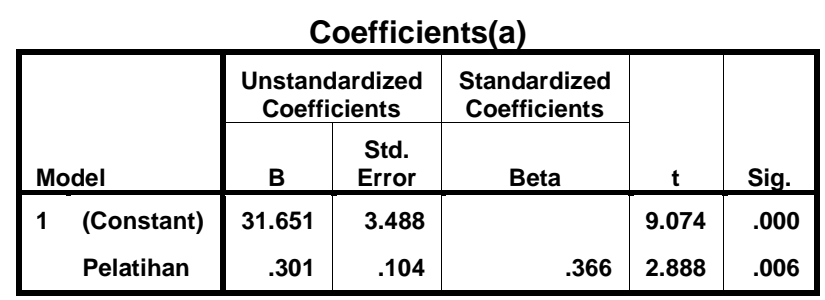

a Dependent Variable: Kinerja Pegawai

Sumber : Data primer (diolah), 2021.

Dari perhitungan dengan menggunakan SPSS versi 20 diatas dapat dibuat sebuah persamaan regresi linier yaitu sebagai berikut :

$$
Y=31,561+0,301 X
$$

Keterangan :

$\mathrm{Y}=$ Kinerja Pegawai

$\mathrm{a}=$ Konstanta

$\mathrm{b}=$ Koefesien regresi

$\mathrm{X}=$ Pelatihan

Interprestasi hasil persamaan di atas sebagai berikut :

a. Nilai konstanta sebesar31,561 menyatakan bahwa jika Pelatihan(X) nilainya adalah 0 , maka Kinerja Pegawai(Y) nilainya adalah 31,561 .

b. Koefisien regresi untukKinerja Pegawai (Y) sebesar0,301 menyatakan bahwa setiap penambahan satu nilai Pelatihan(X), maka nilai Kinerja Pegawai (Y) bertambah sebesar 0,301 .

\section{d. Uji Korelasi.}

Hasil perhitungan korelasi dalam penelitian ini dapat dilihat dari tabel 6 berikut :

Tabel 6. Hasil Uji Korelasi.

\begin{tabular}{l|c|c|r|r|}
\hline Model & $\mathbf{R}$ & $\begin{array}{c}\mathbf{R} \\
\text { Square }\end{array}$ & $\begin{array}{c}\text { Adjusted } \\
\text { R Square }\end{array}$ & $\begin{array}{r}\text { Std. Error of } \\
\text { the Estimate }\end{array}$ \\
\hline 1 & $.366(a)$ & .134 & .118 & 5.678 \\
\hline
\end{tabular}
a Predictors: (Constant), Pelatihan
Sumber: Data primer (diolah), 2021

Dari tabel diatas diketahui nilai korelasi (R) sebesar 0,366, hal ini berarti menunjukkan hubungan yang rendah karena berada di kisaran $0,20-0,399$.

\section{e. Uji Koefisien Determinasi.}

Hasil estimasi uji koefisien determinasi $\left(\mathrm{R}^{2}\right)$ dalam penelitian ini dapat dilihat dari tabel 6 diatas. Dari hasil estimasi data diatas, koefisien determinasi dalam penelitian ini adalah sebesar $\mathbf{0 , 1 3 4}$ atau $\mathbf{1 3 , 4 \%}$, artinya variabel bebas mampu menjelaskan dan memberikan kotribusi terhadap variabel terikat adalah sebesar $\mathbf{1 3 , 4 \%}$, sedangkan sisanya sebesar 86,6\% dijelaskan oleh variabel lain diluar variabel penelitian ini.

\section{f. Uji Hipotesis.}

Penelitian ini dilakukan menggunakan pengujian hipotesis untuk menentukan apakah ada Pelatihan terhadap Kinerja Pegawai dengan kriteria pengujian $t_{\text {hitung }}>t_{\text {tabel }}$ yaitu sebesar 2,00488maka terdapat pengaruh Pelatihan terhadap Kinerja Pegawai.Hasil perhitungan tersebut dapat dilihat dari tabel 5.Dari hasil pengujian hipotesis (uji t) diperoleh nilai thitung sebesar 2,888> tabel sebesar2,00488. Maka dapat disimpulkan bahwa terdapat pengaruh signifikanPelatihan terhadap Kinerja PegawaipadaPerangkat desa Pinang Banjar Kecamatan Sungai Lilin Kabupaten Musi Banyuasin

\section{Implementasi Hasil Penelitian}

Berdasarkan hasil penelitian yang telah dilakukan dan berdasarkan kuesioner yang telah disebarkan didapatlah bahwa hasil koefisien regresi pelatihan sebesar 0,301. Hal ini berarti apabila pelatihan bertambah satu satuan maka, akan meningkatkan 0,301 kinerja perangkat desa. Sedang nilai korelasi variabel pelatihan (R) sebesar 0,366.Dari penafsiran terhadap koefisien korelasi tersebut dapat diketahui bahwa terjadi hubungan yang rendah atau tidak terlalu kuat mempengaruhi kinerja perangkat desa. Sedangkan nilai $\mathrm{R}^{2}$ sebesar 0,134 menunjukkan bahwa variabel pelatihan mempengaruhi kinerja perangkat desa sebesar 13,4 persen, sedangkan sisanya 86,6 persen dipengaruhi oleh variabel lain yang tidak diteliti dalam penelitian ini dan diketahui hasil uji hipotesis (uji t) diketahui nilai $t_{\text {hitung }}>t_{\text {tabel }}$ yaitu 2,888>2,00488, maka $\mathrm{H}_{\mathrm{O}}$ ditolak dan $\mathrm{H}_{\mathrm{a}}$ diterima. Artinya bahwa pelatihan berpengaruh terhadap kinerja perangkat desa pada Desa Pinang Banjar Kecamatan Sungai Lilin.

Hasil penelitian mendukung penelitian terdahulu yang dilakukan oleh Denny 
Triasmok, Moch.Djudi Mukzam dan Gunawan Eko Nurtjahjono (2014), dengan judul penelitian Pengaruh Pelatihan Kerja Terhadap Kinerja Pegawai (Penelitian Pada Pegawai PT. Pos Indonesia (Persero) Cabang Kota Kediri).Berdasarkan hasil penelitian ini diketahui bahwa Pelatihan Kerja yang ada pada PT Pos Indonesia (Persero) Cabang Kota Kediri ternyata mempengaruhi Kinerja Pegawai.Berdasarkan pengujian koefisien determinasi $\left(\mathrm{R}^{2}\right)$ adalah sebesar 0,541 yang artinya variabel metode pelatihan (X1), materi pelatihan (X2), dan instruktur pelatihan (X3) mempunyai pengaruh terhadap kinerja pegawai sebesar $54,1 \%$ dan sisanya sebesar $45,9 \%$ di pengaruhi oleh variabel lain yang tidak diteliti dalam penelitian ini. Selain itu hasil Uji F, dengan nilai sig. $F(0,000)$. Jika nilai sig $F$ $(0,000)$ dibandingkan dengan $\alpha=0.05$, maka sig $\mathrm{F}(0,000)$ lebih kecil dari $\alpha=0.05$ (sig. $\mathrm{F}$ $(0,000)<$ nilai $\alpha=0.05)$, maka Ha diterima sehingga dapat disimpulkan bahwa terdapat pengaruh yang signifikan secara simultan antara variabel bebas Metode Pelatihan (X1), Materi Pelatihan (X2), dan Instruktur Pelatihan (X3) terhadap variabel terikat Kinerja Pegawai (Y).

Hasil penelitian ini juga mendukung hasil penelitian terdahulu yang dilakukan oleh Kelvin Aldrian Widijanto (2017), dengan judul penelitian Pengaruh Pelatihan Kerja Dan Motivasi Kerja Terhadap Kinerja Pegawai Divisi Pemasaran Di PT Sumber Hasil Sejati Surabaya. Berdasarkan analisis data diketahui bahwa penelitian ini memiliki nilai koefisien determinasi $\left(\mathrm{R}^{2}\right)=0,488$. Hal ini menunjukkan bahwa kinerja pegawai di PT Sumber Hasil Sejati Surabaya dipengaruhi oleh variabel pelatihan kerja dan motivasi kerja sebesar $48,8 \%$, dan sebesar $51,2 \%$ dipengaruhi oleh variabel lain yang tidak diuji di dalam penelitian ini dan Pelatihan kerja (X1) berpengaruh positif terhadap kinerja pegawai (Y) yang dapat dilihat dari nilai $t_{\text {hitung }} 4,397$ yang lebih besar daripada nilai $t_{\text {tabel }} 2,040$, dan nilai signifikan 0,000 yang lebih kecil dari $\alpha=$ 0,05 .

\section{Kesimpulan}

Berdasarkan hasil pembahasan pada bab sebelumnya dan perhitungan statistik, maka penulis dapat menyimpulkan bahwa :

1. Berdasarkan hasil estimasi uji validitas diketahui antara indikator terhadap total skor konstruk dari setiap variabel menunjukkan hasil yang signifikan, dan menunjukkan bahwa $r_{\text {hitung }}>r_{\text {tabel }}(0,2632)$. Sehingga dapat disimpulkan bahwa semua item pernyataan dinyatakan valid.

2. Berdasarkan hasil uji reliabilitas diketahui bahwa setiap variabel menunjukkan hasil yang signifikan, dan menunjukkan bahwa nilai koefisien Cronbach's Alpha diatas 0,60 . Sehingga dapat disimpulkan bahwa semua item pernyataan dinyatakan reliabel.

3. Koefisien korelasi sebesar 0,366 menandakan bahwa terdapat hubungan yang positif tapi tidak terlalu kuat atau tidak terlalu mempengaruhi antara variabel pelatihan terhadap kinerja perangkat desa pada kantor Desa Pinang Banjar Kecamatan Sungai Lilin. Disamping itu koefisien determinan $\left(\mathrm{R}^{2}\right)$ sebesar 0,134 menunjukkan bahwa variabel pelatihan dalam penelitian ini mampu menjelaskan 13,4 persen terhadap kinerja perangkat desa pada kantor Desa Pinang Banjar Kecamatan Sungai Lilin, sedangkan sisanya dijelaskan variabel lain diluar penelitian ini.

4. Berdasarkan hasil uji hipotesis (uji t) diketahui bahwa nilai $t_{\text {hitung adalah 2,888 }}$ sedangkan $t_{\text {tabel }} 2,00488$, oleh karena nilai $\mathrm{t}_{\text {hitung }}>\mathrm{t}_{\text {tabel }}$ yaitu 2,888>2,00488, maka $\mathrm{H}_{\mathrm{O}}$ ditolak dan $\mathrm{H}_{\mathrm{a}}$ diterima. Artinya bahwa pelatihan berpengaruh terhadap kinerja perangkat desa pada Desa Pinang Banjar Kecamatan Sungai Lilin

\section{Saran}

Berdasarkan simpulan yang telah dikemukakan, maka dapat diajukan beberapa saran yaitu:

a. Bagi kantor Desa Pinang Banjar Kecamatan Sungai Lilin

1. Hendaknya kantor Desa Pinang Banjar Kecamatan Sungai Lilin dalam meningkatkan kinerja perangkat desa lebih menitik beratkan pada pelatihan baik itu 
tujuan, sasaran, pelatih, materi, metode dan peserta pelatih.

2. Hendaknya pimpinan dalam memberikan pelatihan kepada perangkat desa memperhatikan kesesuain jenis pelatihan yang diberikan. Diketahui dari hasil penyebaran kuesioner terhadap variabel pelatihan kerja terdapat 26 responden yang menyatakan jenis pelatihan yang diberikan kurang sesuai.

3. Hendaknya pimpinan Desa Pinang Banjar mengusulkan pengadaan peralatan pendukung kinerja perangkat desa, karena diketahui dari hasil penyebaran kuesioner terhadap varibel kinerja ada 23 responden menyatakan alat yang digunakan untuk penunjang kinerja perangkat desa banyak yang belum layak atau sudah lama tidak diganti dan sebagian ada yang rusak.

b. Bagi Peneliti Selanjutnya

Bagi para peneliti selanjutnya, khususnya yang tertarik dan berminat untuk mendalami tentang bahasan pelatihan terhadap kinerja, diharapkan mampu untuk mengembangkan penelitian dengan menambah sampel atau populasi yang lebih luas agar dapat menguji variabel lain yang diduga kuat dapat mempengaruhi pelatihanseperti motivasi kerja, komitmen, kepuasan kerja, budaya organisasi dan lain-lain.

\section{DAFTAR PUSTAKA}

Arikunto, Suharsimi. 2012. Prosedur Penelitian. Jakarta: Rineka Cipta.

Bangun, Wilson. 2012. Manajemen Sumber Daya Manusia. Jakarta: Erlangga.

Denny Triasmok, Moch. Djudi Mukzam dan Gunawan Eko Nurtjahjono. 2014. Pengaruh Pelatihan Kerja Terhadap Kinerja Karyawan (Penelitian Pada Karyawan PT. Pos Indonesia (Persero) Cabang Kota Kediri). Jurnal.Di unduh dari https://media.neliti.com. Diakses Tanggal 25 Juni 2021

Fahmi, Irham. 2010. Manajemen Resiko. Bandung: Alfabeta.

Ghozali, Imam. 2016. Aplikasi Analisis Multivariete Dengan Program.IBM SPSS 23 (Edisi 8).Cetakan ke VIII. Semarang: Badan Penerbit.

Hasibuan, Malayu S.P. 2006. Manajemen: Dasar, Pengertian, dan Masalah. (Edisi Revisi). Jakarta: Bumi Aksara.

Kelvin Aldrian Widijanto. 2017. Pengaruh Pelatihan Kerja Dan Motivasi Kerja Terhadap Kinerja Karyawan Divisi Pemasaran Di PT Sumber Hasil Sejati Surabaya,e-journal.unipma.ac.id. Diakses Tanggal 25 Juni 2021.

Ma'ruf, Abdullah. 2014. Metodelogi Penelitian Kuantitatif. Yogyakarta: Aswaja. 
Mangkunegara, A.A. Anwar,Prabu,. 2007. Manajemen Sumber Daya Manusia. Cetakan kelima. Bandung. Remaja Rosdakarya.

Mangkunegara, A.A. Anwar Prabu. 2010.Evaluasi Kinerja SDM.Bandung.Refika Aditama, Bandung.

Moeheriono. 2012. Pengukuran Kinerja Berbasis Kompetensi. Jakarta: Ghalia Indonesia.

Nawawi, Hadari. 2006. Manajemen Sumber Daya Manusia Untuk. Bisnis Yang Kompetitif. Jakarta: PT. Gramedia Widiasarana Indonesia.

Peraturan Pemerintah Nomor 101 Tahun 2000 tentang Pendidikan dan Pelatihan Jabatan.

Pramudyo, Chrisogonus. D. 2007. Cara Pinter Jadi Trainer. Jakarta. Galang Press.

Rivai,Veithzal .2014. Manajemen Sumber Daya Manusia untuk Perusahaan; Edisi keenam. Jakarta. Raja Grafindo Persada

Sedarmayanti.2014. Sumber Daya Manusia dan Produktivitas Kerja. Jakarta: Mandar Maju.

Simamora, Henry. 2006. Manajemen Sumber Daya Manusia, Edisi Ketiga, Yogyakarta: Justine Sirait.

Soesilo, R. 2005. Kitab Undang-Undang Hukum Pidana serta KomentarKomentar Lengkap.Pasal Demi Pasal. Bogor: Penerbit Politeia.

Sugiyono. 2013. Metodologi Penelitian Kuantitatif, Kualitatif Dan $R \& D$. Bandung: Alfabeta.

Sutrisno, Edy.2009, Manajemen Sumber Daya Manusia. Jakarta. Kencana Pernada Media Group.
Suwatno\&

TjutjuYuniarsih.2013.ManajemenSumb er Daya Manusia. Bandung: Alfabeta.

Tika, M. Pabundu. 2012. Budaya Organisasi dan Peningkatan Kinerja Perusahaan. Jakarta: Bumi Aksara.

Undang-Undang Nomor 13 tentang Ketenagakerjaan Tahun 2003.

Wibowo. 2010. Manajemen Kinerja. Jakarta: Rajawali Press. 